\title{
Adherence to Plasmodium vivax malaria treatment in Hanura Public Health Center, Pesawaran District of Indonesia
}

\section{Emantis Rosa}

Universitas Lampung

Indah Dian Shafira

Universitas Lampung Fakultas Kedokteran

Dwita Oktaria

Universitas Lampung Fakultas Kedokteran

Achmad Arifiyanto ( $\square$ achmad.arifiyanto@fmipa.unila.ac.id )

Universitas Lampung https://orcid.org/0000-0002-0224-6309

\section{Research}

Keywords: Malaria vivax, treatment, adherence

Posted Date: January 24th, 2020

DOI: https://doi.org/10.21203/rs.2.21806/v1

License: (c) (1) This work is licensed under a Creative Commons Attribution 4.0 International License. Read Full License 


\section{Abstract}

Background: The Indonesian government has put malaria as a priority disease that needs to be addressed. Lampung is one of the provinces with a high malaria incidence with Annual Paracite Incidence at 4.44 per 1000 population. The most cases occurred in Pesawaran Regency. There were 1.915 malaria cases in 2016. The highest positive case of malaria occurred in the Hanura Health Center with 1.738 cases, with the most cases being vivax malaria. The high case of malaria in the region is due to the favorable natural conditions as mosquito breeding places such as forests, lagoons and abandoned ponds. One of the biggest challenges in the treatment of malaria is the decline in the efficacy of even antimalaria drug resistance due to low adherence in taking the drug. So this research is important to know the level of adherence to take medication in patients with vivax malaria in the work area of the Hanura Health Center.

Methods: This research was a descriptive analytic study with survey methods. Morisky Medication Adherence Scale (MMAS-8) questionnaire was used as the instrument. Eligible patients'who had undergone treatment with Artemisinin-based Combination Therapy and primaquine for 14 days were The subject of study. They were numbered 68 people in the working area of Hanura Health Center.

Results: The level of adherence to take medication in patients with vivax malaria in the working area of Hanura Health Center is classified as low, namely a high compliance rate of $44.1 \%$ and a low compliance rate of $55.9 \%$. The highest proportion of respondents with low levels of adherence were aged 25-45 years (55.3\%), low education level (81.6\%), working (57.9\%), and having a history of malaria more than once $(94,7 \%)$.

Conclusions: The level of adherence to take treatment in patients with vivax malaria in the working area of Hanura Health Center is relatively low, with the highest proportion of adults, low education, work and have a history of malaria more than once.

\section{Background}

Malaria was an infectious disease caused by Plasmodium, which is a single-celled organism that belongs to the Protozoa group. Malaria was transmitted through the bite of a female Anopheles mosquito infected with Plasmodium in her body. Five species of Plasmodium cause malaria in humans, namely Plasmodium falciparum, Plasmodium vivax, Plasmodium malariae, Plasmodium ovale, and Plasmodium knowlesi [1].

Clinical manifestations of malaria were influenced by the patient's immune system, types of Plasmodium, and the number of parasites that infected. Generally the clinical manifestations caused by Plasmodium falciparum were heavier and more acute than other types of Plasmodium, while the symptoms caused by Plasmodium malariae and Plasmodium ovale were the mildest. Malaria trias consist of chills, fever and sweating. The hallmark of malaria was hepatomegaly, splenomegaly, and anemia [2]. 
In 2017 the incidence of malaria in the world reached 216 million cases, so the UN included malaria along with AIDS and tuberculosis in the SDGs (Sustainable Development Goals) [3].

The Indonesian government was also view malaria as a public health threat, especially for people living in remote areas which made malaria a priority disease that needs to be addressed [4].

Lampung was one of the provinces with a high incidence of malaria with Annual Paracite Incidence 4.44 per 1000 population. The most cases occurred in Pesawaran district. In 2016, 1.915 malaria cases were discovered. The highest positive case of malaria occurred in the Hanura Health Center with 1.738 cases, with the most cases being vivax malaria. The high case of malaria in the region was due to the natural conditions that support it as a breeding ground for mosquitoes such as forests, lagoons and abandoned ponds [5].

One of the biggest challenges in the treatment of malaria was the decrease in the efficacy and even resistance of some anti-malaria drugs [6]. Chloroquine, combination of sulfadoxine and pyrimethamine, and mefloquin had known to be resistance. Since 1999 until now used a combination of Artemisininbased Combination Therapy (ACT) and primaquine, but research in Thailand was show that resistance has begun to occur [7].

Resistance was caused by mutations in genes from Plasmodium. The mutated genes that cause Plasmodium falciparum resistance to artemisinin were the K13 gene and the pfATP6 gene [8][9]. The factors that influenced the speed of resistance consisted of operational factors, pharmacological factors and malaria transmission factors. Operational factors included sub therapetic dosing and lack of patient compliance. Malaria transmission factors consisted of intensity, drug pressure and the patient's immune response. Reinfection that often occured in endemic areas also played a role in anti-malaria drug resistance [10].

Compliance was the behavior of individuals in taking medicine, adhering to a diet, or making lifestyle changes according to therapeutic and health recommendations [11]. Compliance with treatment in patients with vivax malaria in some areas was still low. This was due to prolonged treatment (14 days) and its side effects. According to [12] $60.7 \%$ of malaria sufferers in Jambi had low adherence to malaria treatment. Similarly,[13] 56.96\% of malaria sufferers in Banjarnegara District had low adherence to malaria treatment. While in, $56.25 \%$ of malaria sufferers in Jepara were not compliant in undergoing treatment [14].

Several factors that influenced malaria treatment adherence were patient factors, health service system factors, drug factors, and health personnel factors [15]. By age, as many as $62 \%$ of respondents aged 1550 years had low levels of adherence. According to the history of malaria, respondents with a history of malaria more than once had a chance of being obedient 0.8 times [12]. According to work, respondents who worked tend to had low treatment adherence [16]. 
Health service system factors consist of the absence of health insurance, high medical costs, and lack of access to health services. Drug factors were consisted of undesirable effects; the large number of drug consumed, and long treatment. Factors of health workers consisted of poor communication skills of health workers, poor relations with health workers, and the absence of positive encouragement from health workers [15].

Based on the description above, it was known that malaria kept the world's health threats. Treatment of it must be carried out for 14 days to prevent drug resistance. Increase treatment adherence until treatment had completed was one of strategy. In addition, information about drinking compliance in its patient's at Hanura Health Center was not yet known, so this research was important to know the level of treatment adherence in vivax malaria patients, especially in the working area of Hanura Health Center.

\section{Methods}

This research was a descriptive analytic study with survey method. This research was conducted in October to December 2019 in the working area of the Hanura Public Health Center in Pesawaran District to determine the level of compliance with taking treatment in patients with vivax malaria in the region. Samples numbered 68 people with malaria who were diagnosed with malaria in October to November 2019. The research instrument used was the Morisky Medication Adherence Scale (MMAS-8) questionnaire that had been tested for validity and reliability before.

Sample inclusion criteria were vivax malaria sufferers who were diagnosed using the Rapid Diagnostic Test (RDT) and microscopic examination, had finished treatment with a combination of ACT and primaquine for 14 days, aged $\geq 17$ years, lived in the working area of the Hanura Community Health Center and agreed to participate in the study by agreeing informed consent. Sample exclusion criteria were malaria patients who were pregnant and people with severe malaria.

\section{Ethical considerations}

The protocol for the study was evaluated and approved by the Health Research Ethics Committee of Faculty of Medicine The University of Lampung under the opinion No. 3174/ UN2.18/ PP.05.00/ 2019. Those patients who showed malaria symptoms during the interview were referred to the public health centres for medical re-evaluation. Those patients who reported non-adherence to the therapy instructions or still had medication tablets, were instructed to return to the public health centre if their symptoms recur.

\section{Results}

From the results of the study obtained the frequency distribution of the characteristics of respondents as listed in Table 1. In general, all people potentially infected with malaria. The difference in malaria prevalence according to sex and age was related to the level of immunity and variation in susceptibility to mosquito bites [17] Based on sex, it was found that there were more male respondents at $51.5 \%$. 
Table 1 Demography of respondent characteristics

\begin{tabular}{|c|c|c|}
\hline Characteristics & Frequency (n) & Percentage (\%) \\
\hline \multicolumn{3}{|l|}{ Sex } \\
\hline Male & 35 & $51.5 \%$ \\
\hline Female & 33 & $48.5 \%$ \\
\hline \multicolumn{3}{|l|}{ Age (Years) } \\
\hline $17-25$ & 25 & $36.8 \%$ \\
\hline $26-45$ & 33 & $48.5 \%$ \\
\hline$>45$ & 10 & $14.7 \%$ \\
\hline \multicolumn{3}{|l|}{ Level of education } \\
\hline Low (elemntary-junior high school) & 50 & $73.5 \%$ \\
\hline High (senior high school) & 18 & $26.5 \%$ \\
\hline \multicolumn{3}{|l|}{ Jobs } \\
\hline Student & 10 & $14.7 \%$ \\
\hline Housewife & 18 & $26.5 \%$ \\
\hline Fisherman & 15 & $22.1 \%$ \\
\hline Trader & 12 & $17.6 \%$ \\
\hline Others & 8 & $11.8 \%$ \\
\hline Unemployed & 5 & $7.4 \%$ \\
\hline \multicolumn{3}{|l|}{ History } \\
\hline Once & 15 & $22.1 \%$ \\
\hline More than onces & 53 & $77.9 \%$ \\
\hline \multicolumn{3}{|l|}{ Adherences level } \\
\hline Low & 38 & $55.9 \%$ \\
\hline High & 30 & $44.1 \%$ \\
\hline Total & 68 & $100 \%$ \\
\hline
\end{tabular}

Based on age, it was found that respondents aged 26-45 years had the most amount which was $48.5 \%$. This happens because this age was a productive age, where a person usually worked outside the home so it was more susceptible to Anopheles mosquito bites. Busyness due to this activity also made 
respondents less concerned about the prevention of mosquito bites that should be done. This result was in accordance with [18] that $87.65 \%$ of malaria patients were from the adult age group.

Based on the level of education, it was found that there were more respondents with lower levels of education, amounting to $73.5 \%$. This was because the level of education was affect a person in understanding information or knowledge [19]. The low level of education was related to the low awareness to seek and receive information about efforts that can be made to prevent malaria. These results were in accordance with [20] which stated that $68.6 \%$ of malaria sufferers have a low level of education.

Based on work, it was found that most respondents were housewives at $26.5 \%$. This was because many people in the work area of the Hanura Community Health Center operate inside the house but did not close the door of the house due to the hot air, so that mosquitoes could enter the house and caused malaria infection. Malaria patients $44 \%$ were housewives [21]. Most respondents other than housewives were fishermen and fish traders who operated in the coastal area at night until early morning, making it possible to be exposed to Anopheles mosquito bites at that time. This was consistent with the results of the study [22].

Based on the history of malaria, it was found that the majority of respondents had a history of malaria more than once, amounting to $77.9 \%$. This was because the working area of the Hanura Health Center was an endemic area with a high parasitic density so that recurrent malaria infections often occur. Infections that occur were not only vivax malaria, but also Falciparum malaria, ovale malaria and mixed malaria to severe malaria. The high cases in the region due to natural conditions that supported mosquito breeding places such as forests, lagoons and abandoned ponds

Based on the level of medication adherence, it was found that the majority of respondents had a low level of adherence, which was $55.9 \%$.

The distribution of the results of the MMAS-8 questionnaire by respondents can be seen in Table 2 .

\section{Table 2. Distribution of questionnaire results of MMAS-8}




\begin{tabular}{|c|c|c|c|c|}
\hline \multirow[t]{2}{*}{ Questions } & \multicolumn{2}{|c|}{ Yes } & \multicolumn{2}{|c|}{ Not } \\
\hline & $\mathbf{n}$ & $\%$ & & $\%$ \\
\hline 1. Have you ever forgotten to take medicine? & 37 & $54,4 \%$ & 31 & $45,6 \%$ \\
\hline $\begin{array}{l}\text { 2. For other reasons. In the past } 2 \text { weeks have you ever not taken a } \\
\text { medicine? }\end{array}$ & 31 & $45,6 \%$ & 37 & $54,4 \%$ \\
\hline $\begin{array}{l}\text { 3. Have you ever reduced or stopped taking medicine without the } \\
\text { knowledge of your doctor because you felt the medicine given } \\
\text { made your condition worse? }\end{array}$ & 12 & $17,6 \%$ & 56 & $82,4 \%$ \\
\hline 4. Have you ever forgotten to bring medicine in traveling? & 11 & $16,2 \%$ & 57 & $83,8 \%$ \\
\hline 5. Are you still taking your medicine yesterday? & 33 & $48,5 \%$ & 35 & $51,5 \%$ \\
\hline $\begin{array}{l}\text { 6. Do you stop taking treatment when you feel the symptoms have } \\
\text { been resolved? }\end{array}$ & 16 & $23,5 \%$ & 52 & $76,5 \%$ \\
\hline $\begin{array}{l}\text { 7. Taking medicine every day is an inconvenience for some people. } \\
\text { Did you bother having to take medicine every day? }\end{array}$ & 11 & $16,2 \%$ & 57 & $83,8 \%$ \\
\hline $\begin{array}{l}\text { 8. How often do you forget to take medicine? } \\
\text { a. Never } \\
\text { b. Once in a while ( } 1 \text { times in a week) } \\
\text { c. Sometimes }(2-3 \text { times in a week) } \\
\text { d. Usually ( } 4-6 \text { times in a week) } \\
\text { e. Always (7 times in a week) }\end{array}$ & 35 & $51,5 \%$ & 33 & $48,5 \%$ \\
\hline $\begin{array}{l}a=1 \\
b-e=0\end{array}$ & & & & \\
\hline
\end{tabular}

\section{Information :}

$\mathrm{n}=$ number of respondents

Based on Table 2 it was known that the majority of respondents did not take medication due to forgetfulness (question number 1). So there needs to be an effort from the health center, for example by assigning PMO (supervisors taking medication) from the family to remind them to take medicine according to the specified schedule. Besides that, education can be done to activate an alarm or reminder to take medicine every day.

Respondents at least answered "yes" to questions number 4 and number 7 . This was show the high awareness of respondents to carry drugs when traveling during the treatment period. Respondents also did not feel bothered having to take medication every day because of their desire to recover.

The level of adherence to take medication in patients with vivax malaria in the working area of Hanura Health Center was still relatively low as listed in Table 1. This was influenced by various factors, including health service system factors, drug factors, health personnel factors, and patient factors (age, education level, occupation and history of malaria infection). 
The level of adherence to take medication in patients with vivax malaria by age category can be seen in Table 3. In patients with low adherence, the age category of 25-45 years has the greatest proportion of $55.3 \%$. This was because patients in adulthood (25-45 years) were included in the productive age which requires them to work and carry out daily activities. This busyness tends to make patients forget and irregular in undergoing malaria treatment until completion. This was consistent with Farouk's study which states that $62 \%$ of patients aged $15-50$ years have low levels of adherence [12].

\section{Table 3. Adherence level based on age}

\begin{tabular}{|c|c|c|c|c|c|c|c|c|}
\hline \multirow[t]{2}{*}{ Adherence level } & \multicolumn{2}{|c|}{$17-25$ years } & \multicolumn{2}{|c|}{$25-45$ years } & \multicolumn{2}{|c|}{$>45$ years } & \multicolumn{2}{|c|}{ Total } \\
\hline & $\mathrm{n}$ & $\%$ & $\mathrm{n}$ & $\%$ & $\mathrm{n}$ & $\%$ & $\mathrm{n}$ & $\%$ \\
\hline High & 12 & $40 \%$ & 12 & $40 \%$ & 6 & $20 \%$ & 30 & $100 \%$ \\
\hline Low & 13 & $34.2 \%$ & 21 & $55,3 \%$ & 4 & $10,5 \%$ & 38 & $100 \%$ \\
\hline Total & 25 & & 36 & & 10 & & 68 & $100 \%$ \\
\hline \multicolumn{9}{|l|}{ Information: } \\
\hline $\mathrm{n}=$ number of re & ond & & & & & & & \\
\hline
\end{tabular}

The level of adherence to take medication in patients with vivax malaria based on their level of education can be seen in Table 4. In patients with low adherence, the proportion of patients with low education was greater namely $81.6 \%$. This was because education affected all aspects of human life, both thoughts, feelings, and attitudes, including compliance with taking treatment [23].

Table 4 Adherence level based on education level

\begin{tabular}{|lllllll|}
\hline Adherence level & \multicolumn{2}{l}{ High education } & \multicolumn{2}{l|}{ Low education } & \multicolumn{2}{l|}{ Total } \\
\cline { 2 - 8 } & $\mathbf{n}$ & $\%$ & $\mathbf{n}$ & $\%$ & $\mathbf{n}$ & $\%$ \\
\hline High & 11 & $36,7 \%$ & 19 & $63,3 \%$ & 30 & $100 \%$ \\
\hline Low & 7 & $18,4 \%$ & 31 & $81,6 \%$ & 38 & $100 \%$ \\
\hline Total & 18 & & 50 & & 68 & $100 \%$ \\
\hline Information : & & & & & & \\
\hline n = number of respondents & & & & \\
\hline
\end{tabular}

The higher the level of education, the easier it would be to receive information from health workers about the importance of malaria treatment until completion and what risks could occur if treatment was not done properly. This was consistent with research by Wuryanto in Banjarnegara which stated that the level of education would influence a person in understanding information or knowledge [13]. This fact seems 
to be a problem in the working area of the Hanura Community Health Center, because $73.5 \%$ of the population was still low educated. Therefore it was necessary to make efforts to improve medication adherence on the part of the Hanura Community Health Center continuously with a simple language and easily understood by all levels of education.

The level of adherence to take medication in patients with vivax malaria based on work can be seen in Table 5. In patients with low adherence, the number of patients who work had a greater proportion of $57.9 \%$.

Table 5 Adherence level based on jobs

\begin{tabular}{|c|c|c|c|c|c|c|}
\hline \multirow[t]{2}{*}{ Adherence level } & \multicolumn{2}{|c|}{ Employe } & \multicolumn{2}{|c|}{ Unemploye } & \multicolumn{2}{|c|}{ Total } \\
\hline & $\mathrm{n}$ & $\%$ & $\mathbf{n}$ & $\%$ & $\mathbf{n}$ & $\%$ \\
\hline High & 23 & $76,7 \%$ & 7 & $23,3 \%$ & 30 & $100 \%$ \\
\hline Low & 22 & $57,9 \%$ & 16 & $42,1 \%$ & 38 & $100 \%$ \\
\hline Total & 45 & & 23 & & 68 & $100 \%$ \\
\hline \multicolumn{7}{|l|}{ Information : } \\
\hline \multicolumn{7}{|c|}{$\mathrm{n}=$ number of respondents } \\
\hline \multicolumn{7}{|c|}{$\begin{array}{l}\text { This was because the majority of malaria sufferers work as fishermen and fish traders who are active } \\
\text { in catching fish and buying and selling fish at night until early morning. This time is in conjunction } \\
\text { with the medication schedule that was determined by the Hanura Health Center, at } 21: 00 \text { at night so } \\
\text { patients were tend to forget to take treatment at that time. The results of this study were consistent } \\
\text { with Okuboyejo's research which stated that respondents who worked tend to have low treatment } \\
\text { adherence [24]. Therefore it was necessary to do education from the Hanura Health Center to carry } \\
\text { and continue taking the drug even though working. }\end{array}$} \\
\hline
\end{tabular}

The level of adherence to take medication in patients with vivax malaria based on a history of malaria could be seen in Table 6 .

Table 6 Adherence level based on history of malaria 


\begin{tabular}{|c|c|c|c|c|c|c|}
\hline \multirow[t]{2}{*}{ Adherence level } & \multicolumn{2}{|c|}{ History of malaria $>1 \mathrm{x}$} & \multicolumn{2}{|c|}{ History of malaria $1 \mathrm{x}$} & \multicolumn{2}{|c|}{ Total } \\
\hline & $\mathbf{n}$ & $\%$ & $\mathbf{n}$ & $\%$ & $\mathbf{n}$ & $\%$ \\
\hline High & 17 & $56,7 \%$ & 13 & $43,3 \%$ & 30 & $100 \%$ \\
\hline Low & 36 & $94,7 \%$ & 2 & $5,3 \%$ & 38 & $100 \%$ \\
\hline Total & 53 & & 15 & & 68 & $100 \%$ \\
\hline \multicolumn{7}{|l|}{ Information: } \\
\hline $\mathrm{n}=$ number of re & onde & & & & & \\
\hline
\end{tabular}

\section{Discussions}

There were more male respondents infected malaria. This was because the activities of male respondents were done outside the house at night when Anopheles mosquitoes were actively looking for food. The activities carried out were night patrols and working as fishermen and fish traders who were active near the beach at that time. This study was consistent with data from the 2017 Pesawaran District Health Profile which stated that the number of males with malaria was greater than that of females [5].

Patients at productive age were more active outside the home so that it increased the likelihood of being bitten by mosquitoes. The condition of settlements that were closed to mangroves as potential mosquito habitat correlated with the low level of education dominated by women who are mostly housewives. They had low awareness of the potential for mosquito bites when mosquitoes enter the house. It was made them less concerned about the dangers of malaria so they suffer more than once upon malaria.They had a greater proportion of $94.7 \%$. They were assumed that malaria was an ordinary disease so that it did not need special treatment and tended to stop taking treatment when the symptoms that were felt had been resolved.

This differed from research by Farouk which stated that respondents with a history of malaria were more than once likely to be obedient 0.8 times [12]. This fact could be caused by the lack of information from the public health center regarding the importance of undergoing treatment completely to avoid the occurrence of relapse and drug resistance. Counseling that had been carried out only explains about ways to prevent malaria with mosquito nets and maintain environmental cleanliness without the presence of specific and specific information about treatment.

\section{Conclusions}

The level of adherence to take medication in patients with vivax malaria in the working area of Hanura Health Center was still relatively low. In malaria sufferers with low levels of adherence, the highest 
proportion were aged 25-45 years, low education level, working as fishermen and fish traders, and had a history of suffering from malaria more than once.

\section{Declarations}

\section{Acknowledgements}

This research was independent for funding. The authors are grateful to Hanura Public Health Center, Pesawaran District who contributed during the research conducted and all the side who helped research process.

\section{Author details}

${ }^{1}$ Department of Biology, Faculty of Mathematics and Natural Sciences, ${ }^{2}$ Bachelor of Medicine, Faculty of Medicine, University of Lampung, University of Lampung Jl. Prof. Sumantri Brojonegoro 1, Bandarlampung 35145, Indonesia.

\section{Authors' contributions}

ER, and DO conceived and designed the study, IDS conducted the field work and supervised the interview data collection. IDS and AA participated in data management and analysis and wrote the draft of the manuscript. All authors contributed during writing, read and approved the manuscript.

\section{Funding}

This work was funded by author themselves and not affiliated with any party other than the author's institution.

\section{Ethics approval and consent to participate}

The protocol for the study was evaluated and approved by the Health Research Ethics Committee of Faculty of Medicine The University of Lampung under the opinion No. 3174/ UN2.18/ PP.05.00/ 2019. Assent and written informed consent was obtained from participants and their parents/guardians, respectively.

\section{Consent for publication}

Not applicable.

\section{Competing interests}

The authors declare that they have no competing interests.

\section{Data and material availability}


Data and material was available on Mendeley data.

\section{References}

1. Singh B, Daneshvar C: Human infections and detection of Plasmodium knowlesi. Clinical Microbiology Reviews 2013, 26(2):165-84

2. Arsin AA: Malaria di Indonesia tinjauan aspek epidemiologi. Makassar: Masagena Press, 2012.

3. World Health Organization (WHO): Global technical strategy for malaria 2016-2030. Geneva : WHO 2015.

4. Kementerian Kesehatan Rl: Buku saku penatalaksanaan kasus malaria. Jakarta : Kementerian Kesehatan RI, 2017

5. Dinas Kesehatan Kabupaten Pesawaran: Profil kesehatan Kabupaten Pesawaran. Pesawaran : Dinas Kesehatan Kabupaten Pesawaran, 2017.

6. Simamora D, and Fitri LE: Resistensi obat malaria : mekanisme dan peran obat kombinasi anti malaria untuk mencegah. Jurnal Kedokteran Brawijaya 2007, 23(2).

7. Butler AR, Khan S, Ferguson E: A brief history of malaria chemotherapy. JR Coll Physicians Edinb 2010, 40: 172-177

8. Anindita V, Mutiara H, Mutiara UG: Mutasi gen Kelch 13 dan resistensi Plasmodium falciparum terhadap antimalarial golongan artemisinin. Jurnal kedokteran Unila 2017, 7 (5) : 149-153

9. Suwandi JF: Gen PfATP6 dan resistensi Plasmodium falciparum terhadap golongan artemisinin. Jurnal kedokteran Unila 2015, 5 (9) : 141-146

10. Petersen I, Eastman R, and Lanzer M: Drug-resistant malaria : molecular mechanism and implications for public health. FEBS Letters 2011, 585:1551-62

11. Kozier: Buku ajar praktik keperawatan klinis. Edisi 5. Jakarta : EGC, 2010

12. Farouk A: Analisis faktor yang berhubungan dengan kepatuhan pengobatan malaria di Kabupaten Sarolangun Provinsi Jambi tahun 2015. Jurnal IImiah Universitas Batanghari Jambi 2016, 16(1)

13. Wuryanto MA: Beberapa faktor risiko kepatuhan berobat penderita malaria vivax [tesis]. Semarang : Universitas Diponegoro 2005.

14. Utomo DS: Hubungan pengetahuan dan sikap tentang malaria dengan kepatuhan menelan obat pada penderita malaria di Puskesmas Mayong I Jepara tahun 2007 [skripsi]. Semarang : Universitas Dian Nuswantoro 2007

15. Case Management Society of America: Case management adherence guidelines version 2. USA : Case Management Society of America 2006

16. Okuboyejo S: Non-adherence to medication in outpatient setting in Nigeria: the effect of employment status. Global Journal of Health Science 2014, 6 (3) : 37-44

17. Gunawan S: Epidemiologi Malaria. Dalam : Malaria : Epidemiologi, Manifestasi Klinis dan Penanganan. Jakarta : EGC 2000 
18. Syah IF: Hubungan karakteristik individu, perilaku dan lingkungan dengan kejadian malaria di wilayah Puskesmas Girian Weru Kota Bitung tahun 2012 [skripsi]. Program Studi Kesehatan Masyarakat : Universitas Indonesia

19. Notoatmodjo S: Kesehatan masyarakat. Ilmu dan seni. Jakarta : PT. Rineka Cipta. 2009

20. Manumpa S: Pengaruh faktor demografi dan riwayat malaria terhadap kejadian malaria. Jurnal Berkala Epidemiologi 2016, 4 (3) : 338-348

21. Mooduto PT: Karakteristik penderita malaria di wilayah kerja Puskesmas Bongomeme Kabupaten Gorontalo. [skripsi] Jurusan Kesehatan Masyarakat. Universitas Negeri Gorontalo 2012

22. Novelina C: Karakteristik penderita malaria di wilayah kerja Puskesmas Sambau Kecamatan Nongsa Kota Batam. Jurnal Gizi, Kesehatan Reproduksi dan Epidemiologi 2012, 1 (1)

23. Astuti W: Hubungan perilaku vulva hygiene dengan kejadian keputihan pada remaja putri kelas $X$ di SMU Negeri 2 Ungaran Semarang. Jurnal Kebidanan dan Keperawatan 2008, 4 (2) : 59-65

24. Okuboyejo S: Non-adherence to medication in outpatient setting in Nigeria : the effect of employment status. Global Journal of Health Science 2014, 6 (3): 37-44 